Article

\title{
High-Level Expression of a Thermally Stable Alginate Lyase Using Pichia pastoris, Characterization and Application in Producing Brown Alginate Oligosaccharide
}

\author{
Haifeng Li ${ }^{1}$, Shuling Wang ${ }^{1}$, Yunyi Zhang ${ }^{2, *}$ (1) and Liehuan Chen ${ }^{3, *}$ \\ 1 College of Medicine, Hangzhou Normal University, Hangzhou 311121, China; lihf@hznu.edu.cn (H.L.); \\ wsling222@163.com (S.W.) \\ 2 Department of Microbiology, Zhejiang Provincial Center for Disease Control and Prevention, \\ Hangzhou 310051, China \\ 3 College of Animal Sciences and Technology, Zhongkai University of Agriculture and Engineering, \\ Guangzhou 510225, China \\ * Correspondence: yyzhang@cdc.zj.cn (Y.Z.); Chitins@126.com (L.C.); \\ Tel.: +86-571-8711-5280 (Y.Z.); +86-20-8900-2133 (L.C.)
}

Received: 25 March 2018; Accepted: 7 May 2018; Published: 11 May 2018

\begin{abstract}
An alginate lyase encoding gene sagl from Flavobacterium sp. H63 was codon optimized and recombinantly expressed at high level in P. pastoris through high cell-density fermentation. The highest yield of recombinant enzyme of sagl (rSAGL) in yeast culture supernatant reached $226.4 \mu \mathrm{g} / \mathrm{mL}(915.5 \mathrm{U} / \mathrm{mL})$. This was the highest yield record of recombinant expression of alginate lyase so far. The rSAGL was confirmed as a partially glycosylated protein through EndoH digestion. The optimal reaction temperature and $\mathrm{pH}$ of this enzyme were $45^{\circ} \mathrm{C}$ and $7.5 ; 80 \mathrm{mM} \mathrm{K}^{+}$ions could improve the catalytic activity of the enzyme by $244 \%$ at most. rSAGL was a thermal stable enzyme with $\mathrm{T} 50^{15}$ of $57-58{ }^{\circ} \mathrm{C}$ and $\mathrm{T} 50^{30}$ of $53-54{ }^{\circ} \mathrm{C}$. Its thermal stability was better than any known alginate lyase. In $100 \mathrm{mM}$ phosphate buffer of $\mathrm{pH} 6.0$, rSAGL could retain $98.8 \%$ of the initial activity after incubation at $50{ }^{\circ} \mathrm{C}$ for $2 \mathrm{~h}$. Furthermore, it could retain $61.6 \%$ of the initial activity after $48 \mathrm{~h}$. The specific activity of the purified rSAGL produced by P. pastoris attained $4044 \mathrm{U} / \mathrm{mg}$ protein, which was the second highest record of alginate lyase so far. When the crude enzyme of the rSAGL was directly used in transformation of sodium alginate with $40 \mathrm{~g} / \mathrm{L}, 97.2 \%$ of the substrate was transformed to di, tri, tetra brown alginate oligosaccharide after $32 \mathrm{~h}$ of incubation at $50{ }^{\circ} \mathrm{C}$, and the final concentration of reducing sugar in mixture reached $9.51 \mathrm{~g} / \mathrm{L}$. This is the first report of high-level expression of thermally stable alginate lyase using P. pastoris system.
\end{abstract}

Keywords: Pichia pastoris; alginate lyase; expression; oligosaccharide

\section{Introduction}

Alginate is a kind of linear anionic polymer composed of $\alpha$-L-guluronate and its C5 epimer $\beta$-D-mannuronate. Alginate is the major cell wall polysaccharides of brown algae. Alginate lyase can catalyze the degradation of alginate to produce oligosaccharides, which have been confirmed to have many biological activities [1]. Brown alginate oligosaccharide has been applied extensively in food, medicine, and agriculture. Alginate lyases with high catalytic activity are the key factors during the process of oligosaccharides production using alginate as raw materials. Meanwhile, sufficient supply of alginate lyase is also important for oligosaccharides production. Alginate lyases have been found in many marine bacteria, fungi, and invertebrate. A variety of types of wild microorganisms 
which could produce alginate lyase had been found and investigated. However, low yield of alginate lyases in these isolates limited their applications. Recombinant expression of alginate lyases in engineering microorganisms is a good resolution for this problem. To date, some alginate lyases have been successfully recombinantly expressed in Escherichia coli system [1,2]. However, no high enzyme yields satisfying industrial need were obtained in these reports. Furthermore, the recombinant protein produced by E. coli usually was not be recommended to use in food and feed industry because of safety of residual endotoxin. Comparing to E. coli, Pichia pastoris was used to produce enzyme for pharmaceutical and food industries more frequently in the past two decades. This system had advantages of efficient extracellular protein secretion capacity, convenient product separation process, and no endotoxin production. In one report, a chitosanase from Bacillus subtilis HD145 was recombinantly produced by Pichia pastoris system. The yield reached $800 \mathrm{mg} / \mathrm{L}$ after optimization of fermentation conditions [3]. Pichia pastoris system usually is first choice in production of industrial-scale recombinant proteins, but there were almost no reports of alginate lyases recombinantly expressed in P. pastoris system so far. Exploring the potential application of P. pastoris in alginate lyase production is worth studying. In this study, an alginate lyase gene sagl from Flavobacterium sp. H63 was successfully expressed in P. pastoris with high-level yield. Before now, this sagl gene has not been well expressed in E. coli system because of an inclusion body problem. Meanwhile, the characteristics of this recombinant alginate lyase produced by yeast were investigated in detail. In addition, the large-scale production of brown alginate oligosaccharide using this recombinant enzyme was studied.

\section{Results and Discussion}

\subsection{Recombinant Expression of SAGL in Escherichia coli}

Recombinant $E$. coli carrying pET28a-nagl vector was induced and tested by SDS-PAGE. Most recombinant alginate lyase were in insoluble inclusion body form in E. coli of BL21(DE3) (Figure 1). This recombinant alginate lyase in supernatant of cell lyaste was purified using Ni-NTA resin (Figure 1, lane 5). The yield of only 10 units per $\mathrm{mL}$ culture was obtained using E. coli system.

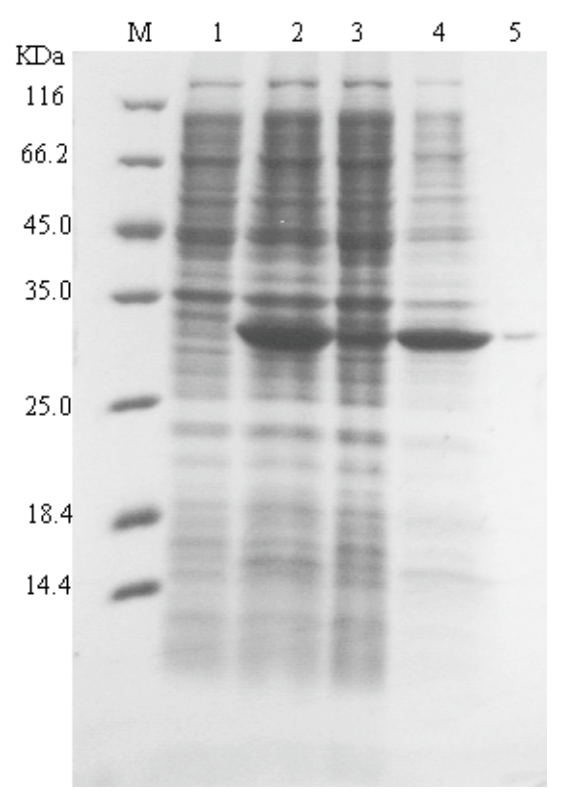

Figure 1. SDS-PAGE analysis of SAGL expression in the E. coli system. Lane M protein marker; lane 1 cell lysate of BL21(DE3); lane 2 whole cell lysate of BL21(DE3) with pET28a-vectors; lane 3 supernatant of cell lysate with recombinant vectors; lane 4 precipitate of cell lysate with recombinant vectors; lane 5 purified recombinant alginate lyase. 


\subsection{Recombinant Expression of SAGL Using P. pastoris in Flask}

A linearized recombinant vector pPICZ $\alpha$ A carrying sagl alginate lyase gene was transformed into P. pastoris X33 competent cells by using electroporation. More than 400 positive yeast colonies selected using PCR were inoculated on screening plates. A yeast colony with the largest hydrolytic circle around the colony was selected. The ratio of the diameter of hydrolytic circle to that of this colony reached about 4:1. The shaking flask fermentation of this strain proceeded. After $168 \mathrm{~h}$ of fermentation, the activity of recombinant SAGL protein in supernatant reached maximum of $93.5 \mathrm{U} / \mathrm{mL}$. The protein expression of this strains in shaking flask was analyzed by using SDS-PAGE. Two protein bands with molecular weight (MW) of $35 \mathrm{KDa}$ and $32 \mathrm{KDa}$ were detected in crude supernatant samples from recombinant strain without concentration treatment (Figure 2a), but the protein content of the $35 \mathrm{KDa}$ band was much lower than that of the $32 \mathrm{KDa}$ band. After purification using Ni-NTA resin, the enzyme was still constituted of two bands of $35 \mathrm{KDa}$ and $32 \mathrm{KDa}$ (Figure 2b). The value of $32 \mathrm{KDa}$ was consistent with calculated MW of recombinant SAGL alginate lyase, whereas after deglycosylation treatment using Endo $\mathrm{H}$ two protein bands comigrated into one $32 \mathrm{KDa}$ band in SDS-PAGE (Figure 2b). Next, mouse anti His antibody was used in Western blotting. Two blots represented two protein bands of recombinant SAGL were developed (Figure 2c). It was confirmed that two protein bands both contained histidine tag. The $32 \mathrm{KDa}$ band was unglycosylated recombinant SAGL protein and the $35 \mathrm{KDa}$ band consisted of glycosylated ones.

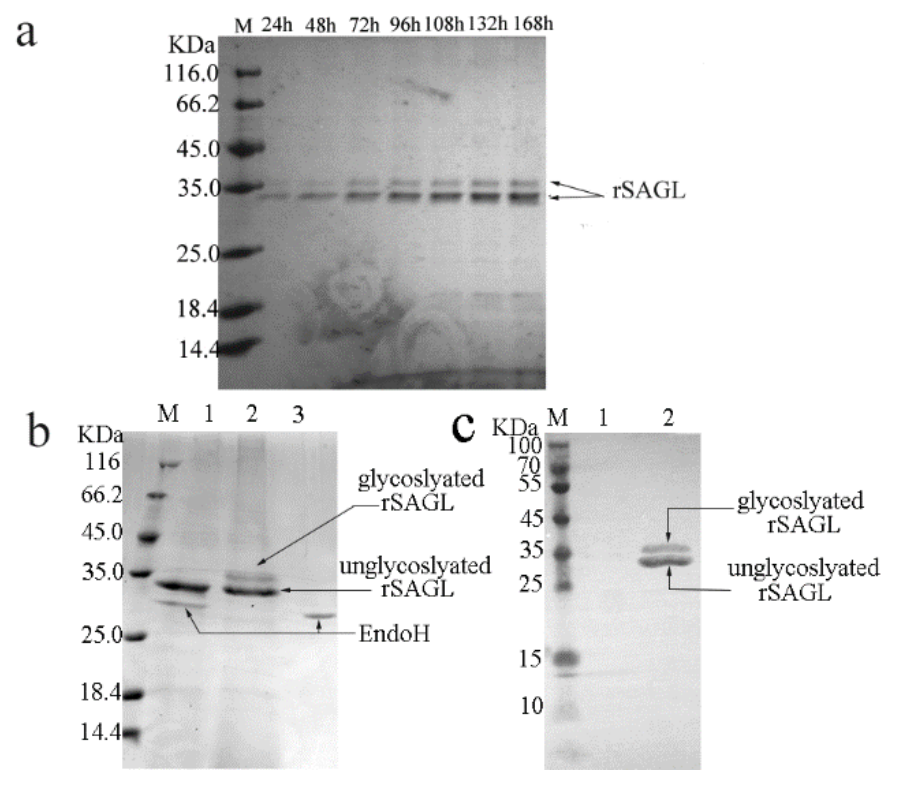

Figure 2. Expression in flask fermentation, glycosylation, and western-blotting analysis of rSAGL. (a) SDS-PAGE analysis of SAGL expression in shaking flask. BMMY medium was used in shaking flask. Culture supernatant samples collected at $24 \mathrm{~h}$ intervals were tested by electrophoresis. The target protein bands represented rSAGL were marked by arrows; (b) glycosylation analysis of purified rSAGL. Lane $\mathrm{M}$ protein marker; lane 1 unglycosylated rSAGL, EndoH protein band were marked by arrows; lane 2 purified rSAGL control, glycosylated and unglycosylated rSAGL protein band were marked by arrows; lane 3 EndoH blank control; (c) western -blotting of purified rSAGL. Lane M protein marker; lane 1 BSA control; lane 2 purified rSAGL.

Glycosylation of recombinant proteins expressed in Pichia yeast has been reported previously. For example, a chitosanase from Bacillus subtilis HD145 was recombinantly expressed in P. pastoris. The recombinant chitosanase enzyme was also partially glycosylated and constituted of two protein bands with $33 \mathrm{KDa}$ and $31 \mathrm{KDa}$. [3]. It was confirmed that thermal stability of recombinant chitosanase was better than native enzyme from Bacillus subtilis extract. The author speculated 
that the improvement of thermal stability was caused by the glycosylation of protein. These results in Figure 2 showed that SAGL alginate lyase was successfully expressed in P. pastoris in flask. At the end of fermentation, the yield of alginate lyase in flask reached $23.1 \mu \mathrm{g} / \mathrm{mL}$ culture (about $95 \mathrm{U} / \mathrm{mL}$ at optimum testing condition). There was only one public report about the recombinant expression of alginate lyase using P. pastoris system [4]. The alginate lyase gene paAlgL from Pseudomonas aeruginosa PAOI was recombinantly expressed in P. pastoris GS115, and the specific activity of the recombinant paAlgL reached $2440 \mathrm{U} / \mathrm{mg}$ protein, but no yield data was shown. In that paper the reason of choosing P. pastoris rather than E. coli was that the recombinant target proteins in the latter system tended to be inclusion body and the complicated purification procedures caused significant decrease in yield of recombinant alginate lyase. The recombinant paAlgL alginate lyase produced by Pichia yeast was not glycosylated and there were no comparison results between recombinant alginate lyase produced by P. pastoris and E. coli in that paper.

\subsection{Characterization of Recombinant sagl from E. coli and P. pastoris Systems}

In our early flask experiment, the expression of sagl gene in E. coli BL21(DE3) was not well, although we made a lot of efforts including changing of expression vector, host strain, and gene codons optimization (data not shown). The main target enzyme was still expressed as inclusion body form (Figure 1, line 4). After Ni-affinity chromatography purification, the yield of recombinant alginate lyase was determined as about 10 units per microliter culture. This yield was too low to apply the recombinant enzyme in scale oligosaccharide production, so we chose the P. pastoris system and obtained significant improvement of yield. For detailed characterization of rSAGL expressed by yeast, rSAGL produced by E. coli was purified and used as a comparison of non-glycosylated rSAGL. After determination, the specific activity of partially glycosylated rSAGL from P. pastoris and non-glycosylated rSAGL from E. coli were almost equal $(2080 \mathrm{U} / \mathrm{mg}$ protein vs. $2133 \mathrm{U} / \mathrm{mg}$ protein). The $K \mathrm{~m}$ values against sodium alginate of the two enzymes were almost same $(4.63 \mathrm{mg} / \mathrm{mL}$ vs. $4.64 \mathrm{mg} / \mathrm{mL}$ ). Concerning thermal stability, there was no significant difference between the two enzymes when they were incubated at $50{ }^{\circ} \mathrm{C}$ in $100 \mathrm{mM} \mathrm{Na} 2 \mathrm{HPO}_{4}-\mathrm{NaH}_{2} \mathrm{PO}_{4}$ buffer (pH 6.0). They could both maintain about $60 \%$ and $50 \%$ of initial activity at $48 \mathrm{~h}$ and $72 \mathrm{~h}$ (Figure 3). It was concluded that partial glycosylation of rSAGL had no effect on its thermal stability, specific activity, and substrate affinity ability against sodium alginate. rSAGL produced by P. pastoris and E. coli both were thermally stable at $50{ }^{\circ} \mathrm{C}$. Partial glycosylation had no obvious impact on the stability of rSAGL produced by P. pastoris.

The optimal reaction temperature of this rSAGL enzyme was determined as $45^{\circ} \mathrm{C}$ (Figure 4a). Most known alginate lyases were not thermally stable; they exhibited optimal catalytic activity between $30{ }^{\circ} \mathrm{C}$ and $40{ }^{\circ} \mathrm{C}$. There were few thermophilic alginate lyase. A recombinant alginate lyase from Saccharophagus degradans had optimum catalytic temperature of $50{ }^{\circ} \mathrm{C}$, but it lost $58 \%$ of initial activity at $50{ }^{\circ} \mathrm{C}$ after $30 \mathrm{~min}$ [5]. A recombinant alginate lyase from Nitratiruptor sp. SB155-2 possessed optimum catalytic temperature of $70{ }^{\circ} \mathrm{C}$, but it lost $80 \%$ of initial activity by incubation at $50{ }^{\circ} \mathrm{C}$ for $16 \mathrm{~h}$ [6]. The optimal catalytic pH of rSAGL was 7.5 (Figure 4b). Most known alginate lyases exhibited best catalytic activity between $\mathrm{pH} 6.0$ and 8.0.

Metal ions can affect enzyme activity by large extent. In our test, most metal ions could inhibit enzyme activity of rSAGL, except for $\mathrm{Mg}^{2+}, \mathrm{Na}^{+}$, and $\mathrm{K}^{+}$. These three kinds of ions all could improve activity by different degrees. $\mathrm{Mg}^{2+}$ of $100 \mathrm{mM}$ could improve the catalytic activity of rSAGL by $47 \%$ (Table 1).

$\mathrm{Na}^{+}$and $\mathrm{K}^{+}$ions known as activator of some alginate lyases could significantly improve the activity of rSAGL. $\mathrm{K}^{+}$ions of $80 \mathrm{mM}$ were found to have the best catalytic activity improvement of rSAGL by $244 \%$ (Table 2). By combination of the above parameters, the specific activity of rSAGL was improved from $2080 \mathrm{U} / \mathrm{mg}$ to $4044 \mathrm{U} / \mathrm{mg}$ under optimum catalytic conditions including $45^{\circ} \mathrm{C}, 80 \mathrm{mM}$ $\mathrm{K}_{2} \mathrm{HPO}_{4}-\mathrm{KH}_{2} \mathrm{PO}_{4}$ buffer $(\mathrm{pH} 7.5)$ and $10 \mathrm{~g} / \mathrm{L}$ sodium alginate substrate. This specific activity was the second highest record of alginate lyase activity by comparing with known alginate lyases [7]. 


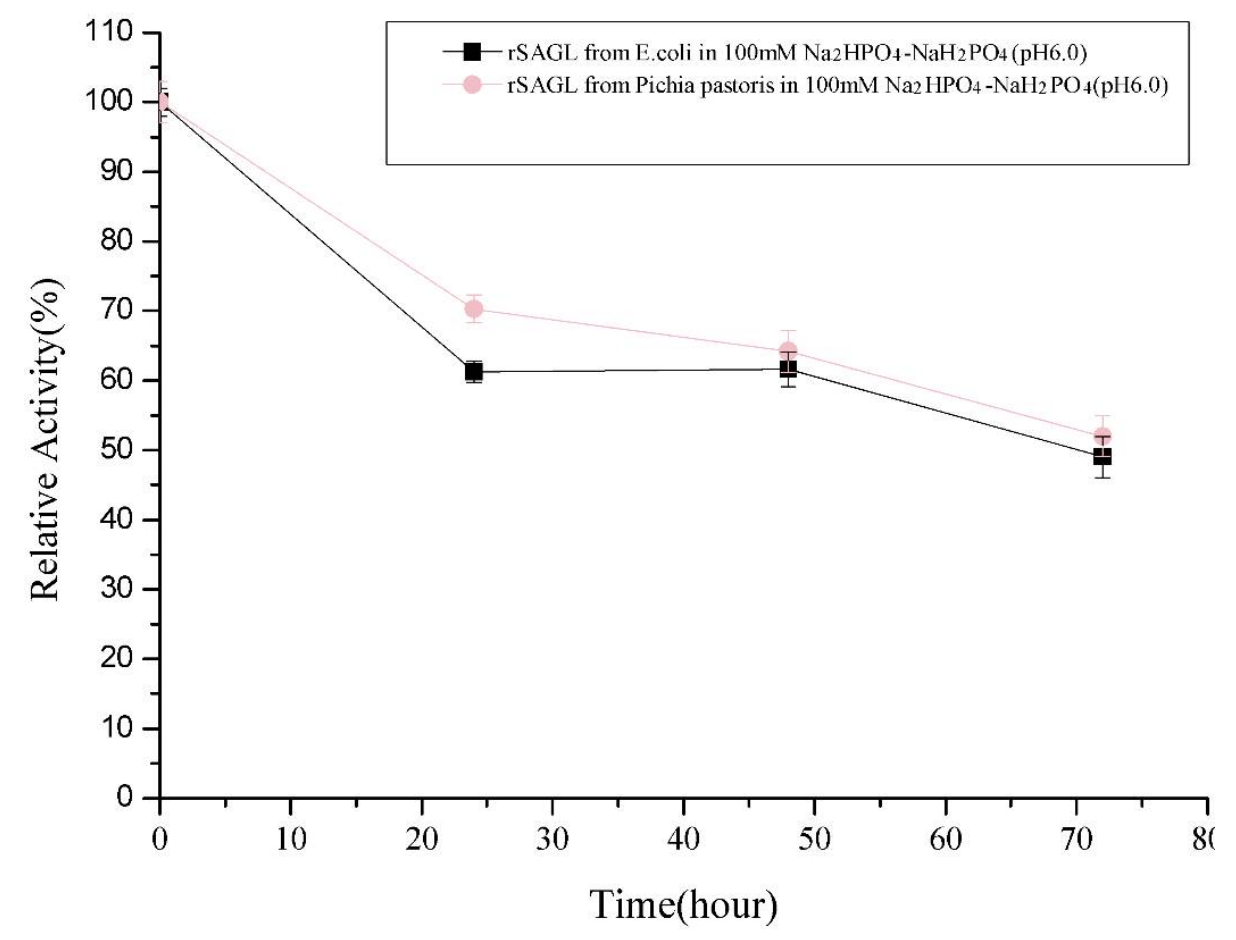

Figure 3. Comparison of thermal stability at $50{ }^{\circ} \mathrm{C}$ between rSAGL from E. coli and rSAGL from $P$. pastoris. The purified recombinant enzymes from above two microorganisms were stored in $100 \mathrm{mM}$ $\mathrm{Na}_{2} \mathrm{HPO}_{4}-\mathrm{NaH}_{2} \mathrm{PO}_{4}$ buffer ( $\mathrm{pH}$ 6.0) and incubated at $50{ }^{\circ} \mathrm{C}$ for $72 \mathrm{~h}$. All experiments were conducted in triplicate, and the data were expressed as mean \pm standard deviation.
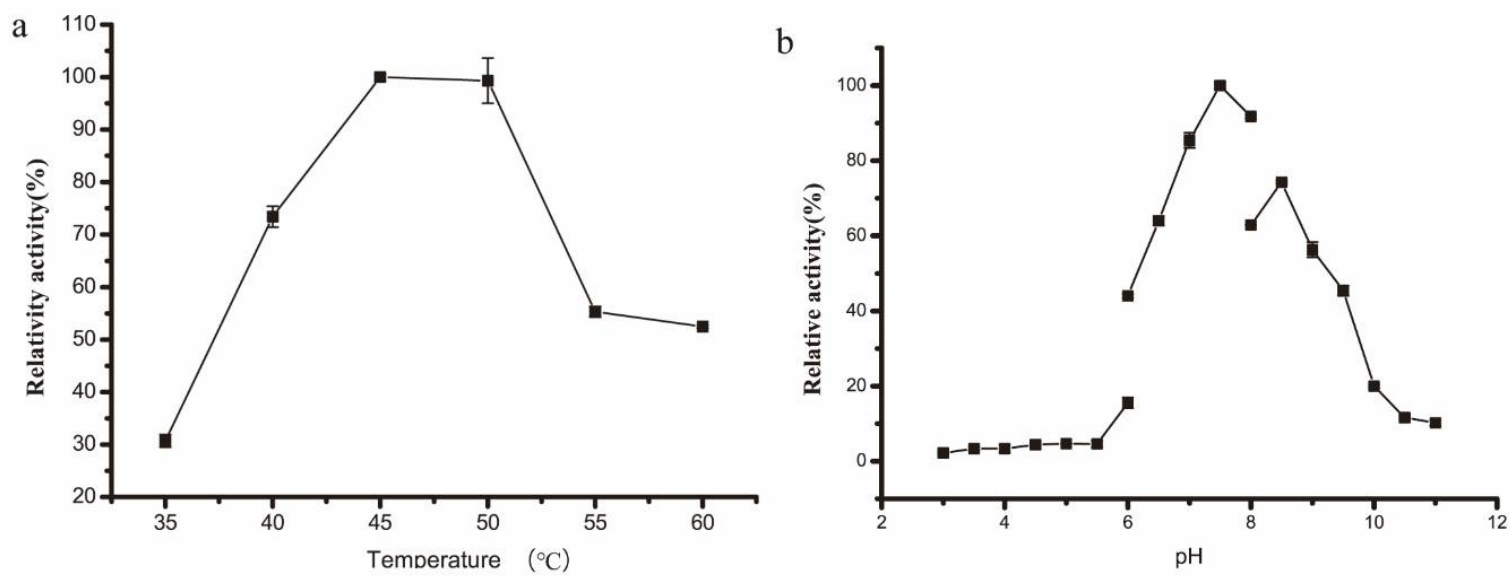

Figure 4. Optimization of catalytic temperature (a) and $\mathrm{pH}(\mathbf{b})$ of rSAGL from $P$. pastoris. $\mathrm{Na}_{2} \mathrm{HPO}_{4}-\mathrm{NaH}_{2} \mathrm{PO}_{4}$ buffer (100 mM, pH 6.0) and sodium alginate were used as standard buffer and standard substrate in tests. All experiments were conducted in triplicate, and the data were expressed as mean \pm standard deviation. 
Table 1. Metal ions effect on the activity of rSAGL.

\begin{tabular}{|c|c|c|}
\hline Metal Ion & Ion Concentration & Relative Activity \\
\hline \multirow{2}{*}{$\mathrm{Mn}^{2+}$} & $1 \mathrm{mM}$ & 0 \\
\hline & $10 \mathrm{mM}$ & 0 \\
\hline \multirow{2}{*}{$\mathrm{Cu}^{2+}$} & $1 \mathrm{mM}$ & 0 \\
\hline & $10 \mathrm{mM}$ & 0 \\
\hline \multirow{2}{*}{$\mathrm{Co}^{2+}$} & $1 \mathrm{mM}$ & 0 \\
\hline & $10 \mathrm{mM}$ & 0 \\
\hline \multirow{2}{*}{$\mathrm{Ca}^{2+}$} & $1 \mathrm{mM}$ & $74 \pm 0.2$ \\
\hline & $10 \mathrm{mM}$ & 0 \\
\hline \multirow{3}{*}{$\mathrm{Mg}^{2+}$} & $1 \mathrm{mM}$ & $106 \pm 0.6$ \\
\hline & $10 \mathrm{mM}$ & $93 \pm 1.3$ \\
\hline & $100 \mathrm{mM}$ & $147 \pm 0.9$ \\
\hline \multirow{2}{*}{$\mathrm{Ag}^{+}$} & $1 \mathrm{mM}$ & 0 \\
\hline & $10 \mathrm{mM}$ & 0 \\
\hline \multirow{2}{*}{$\mathrm{Zn}^{2+}$} & $1 \mathrm{mM}$ & $15 \pm 0.4$ \\
\hline & $10 \mathrm{mM}$ & 0 \\
\hline \multirow{2}{*}{$\mathrm{Ni}^{+}$} & $1 \mathrm{mM}$ & $29 \pm 0.7$ \\
\hline & $10 \mathrm{mM}$ & 0 \\
\hline \multirow{2}{*}{$\mathrm{Fe}^{3+}$} & $1 \mathrm{mM}$ & $5.3 \pm 0.2$ \\
\hline & $10 \mathrm{mM}$ & $14 \pm 1.1$ \\
\hline Control enzyme & 0 & $100 \pm 3.4$ \\
\hline
\end{tabular}

Table 2. Na and $\mathrm{K}$ ions effect on activity.

\begin{tabular}{ccc}
\hline \multirow{2}{*}{ Ions Concentration (mM) } & \multicolumn{2}{c}{ Relative Activity (\%) } \\
\cline { 2 - 3 } & $\mathbf{N a C l}$ & $\mathbf{K C l}$ \\
\hline 0 & 100 & 100 \\
10 & $201 \pm 2.4$ & $237 \pm 5.6$ \\
20 & $292 \pm 4.1$ & $274 \pm 3.5$ \\
50 & $168 \pm 5.4$ & $270 \pm 1.7$ \\
80 & $135 \pm 8.3$ & $344.4 \pm 2.9$ \\
100 & $246 \pm 1.2$ & $325 \pm 2.7$ \\
150 & $120 \pm 5.0$ & $300 \pm 6.2$ \\
200 & $131.5 \pm 6.1$ & $283.7 \pm 7.5$ \\
300 & $140 \pm 3.3$ & $215 \pm 1.8$ \\
400 & $215 \pm 4.6$ & $147 \pm 0.4$ \\
500 & $197 \pm 5.3$ & $177 \pm 8.0$ \\
\hline
\end{tabular}

\subsection{End Product Analysis}

Through ESI-MS analysis of molecular weight, the end hydrolysis products of sodium alginate substrate were determined as mixture of disaccharide, trisaccharide, and tetrasaccharide (Figure 5). These oligosaccharides existed as sodium salt form. The catalytic mode of rSAGL was confirmed as endo manner because no monosaccharide product was found. The product spectrum of rSAGL was similar to that of most endo-type alginate lyase. The spectrums of these enzymes were all focused on a range of 2-7 polymerization degree with low molecular weight, and it was acknowledged that oligosaccharide with low molecular weight usually had better biological activity. 


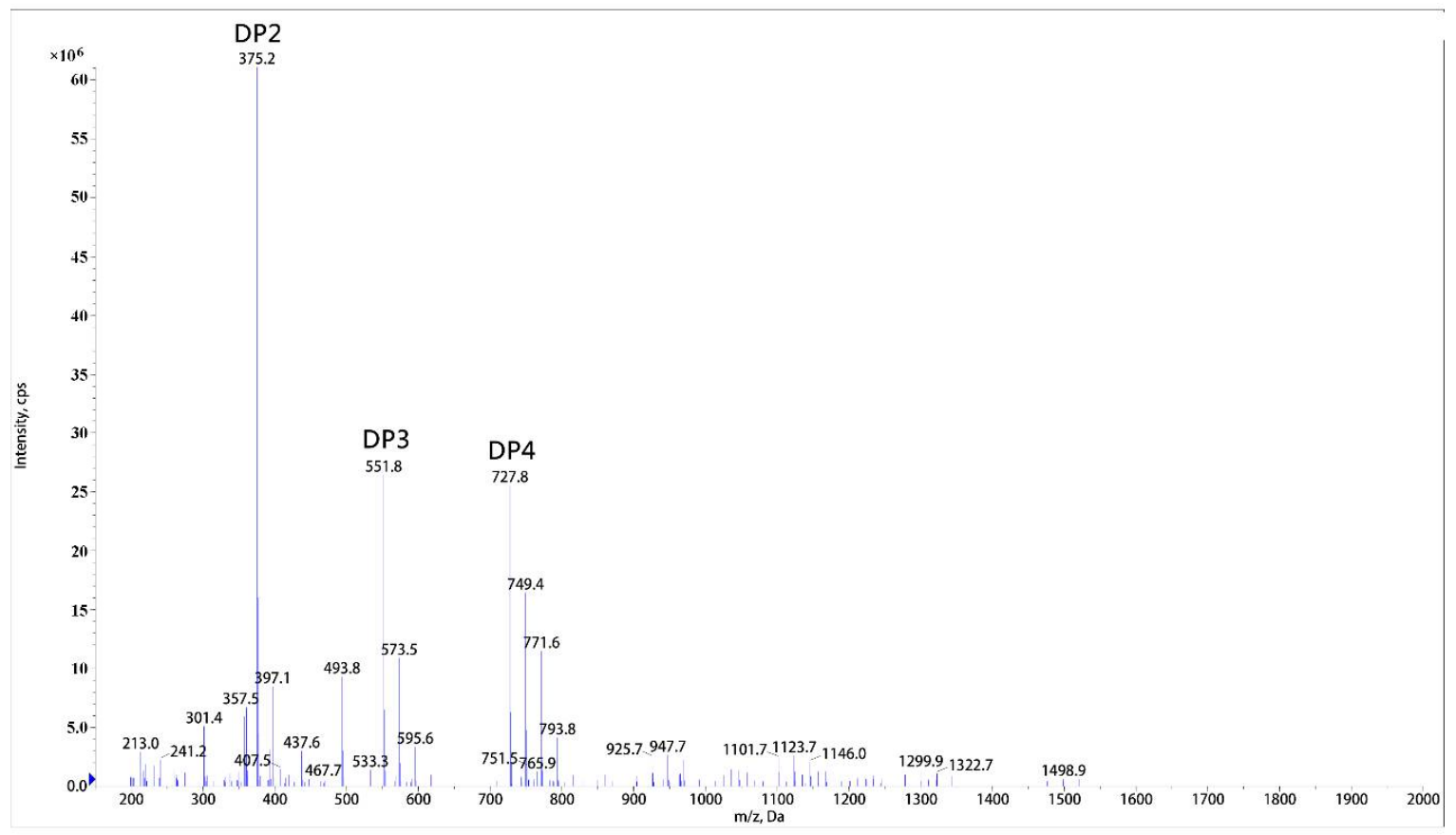

Figure 5. ESI-MS analysis of end hydrolysis product of rSAGL. Sodium alginate was used as substrate in test. DP2,3,4 peak represented disaccharide, trisaccharide, tetrasaccharide of alginate oligosaccharide. DP2 (disaccharide $m / z 352+\mathrm{Na}^{+}: m / z$ 375.2), DP3 (trisaccharide $m / z 528+\mathrm{Na}^{+}: m / z 551.8$ ), and DP4 (tetrasaccharide $m / z 704+\mathrm{Na}^{+}: m / z$ 727.8).

\subsection{Characterization of Thermal Stability of rSAGL}

The thermal stability of rSAGL from $P$. pastoris was impressive. It could retain $49.0 \%$ of initial activity after incubation at $50{ }^{\circ} \mathrm{C}$ in phosphate salt buffer (pH 6.0) for $72 \mathrm{~h}$ (Figure 3). In the same buffer, T50 values of rSAGL at $15 \mathrm{~min}$ and $30 \mathrm{~min}$ were determined as $57-58{ }^{\circ} \mathrm{C}\left(\mathrm{T} 50^{15}\right)$ and $53-54{ }^{\circ} \mathrm{C}$ $\left(\mathrm{T} 50^{30}\right)$. Next, it was necessary to verify if the incubation buffer had significant effects on the thermal stability of rSAGL. The result in Figure 6a indicated that $100 \mathrm{mM} \mathrm{Na} 2 \mathrm{HPO}_{4}-\mathrm{NaH}_{2} \mathrm{PO}_{4}$ buffer $(\mathrm{pH} 6.0$ and $\mathrm{pH}$ 7.0) had better performance than Tris- $\mathrm{HCl}$ and $\mathrm{HAc}-\mathrm{NaAc}$ buffer in the thermal stability test at $50{ }^{\circ} \mathrm{C}$ for $120 \mathrm{~min}$. When the incubation temperature was increased to $55^{\circ} \mathrm{C}$, rSAGL also could retain $78.9 \%$ of initial activity after $1.5 \mathrm{~h}$ incubation in phosphate salt buffer of $\mathrm{pH} 6.0$ (Figure 6b). However, the enzyme sample in phosphate salt buffer of $\mathrm{pH} 7.0$ only retain $12.1 \%$ of initial activity after $1.5 \mathrm{~h}$ incubation at $50{ }^{\circ} \mathrm{C}$. It was concluded that phosphate salt buffer with $\mathrm{pH} 6.0$ was most advantageous to the stability of rSAGL. This enzyme was very stable in this buffer at temperatures lower than $50{ }^{\circ} \mathrm{C}$.

During the process of alginate lyases catalysis, high catalytic temperature can facilitate the transformation of substrate due to the reduction of viscosity of reaction mixture and improvement of enzyme activity. High process temperature (above $45{ }^{\circ} \mathrm{C}$ ) can also prevent microorganism contamination when crude substrate such as kelp powder is transformed. Alginate lyases with good thermal stability are very valuable for enzymatic production of brown algae oligosaccharide. However, most known alginate lyases are not thermally stable. The possible reason was that they were mainly from marine bacteria which were isolated from low temperature locations [7-11].

\subsection{Comparison of Catalytic Property}

The specific activity and thermal stability of rSAGL were impressive. It was necessary to compare its catalytic property with some reported endo-type alginate lyases [1,2,4-16]. The property parameters of these alginate lyase enzymes are shown in Table 3. The specific activity of rSAGL ( $4044 \mathrm{U} / \mathrm{mg}$ ) was the second highest record among known alginate lyases. The thermal stability of rSAGL produced 
by P. pastoris at $50{ }^{\circ} \mathrm{C}$ was also the highest comparing other enzymes in Table 3. These catalytic properties made rSAGL a promising enzyme for the transformation of sodium alginate to produce brown alginate oligosaccharide.
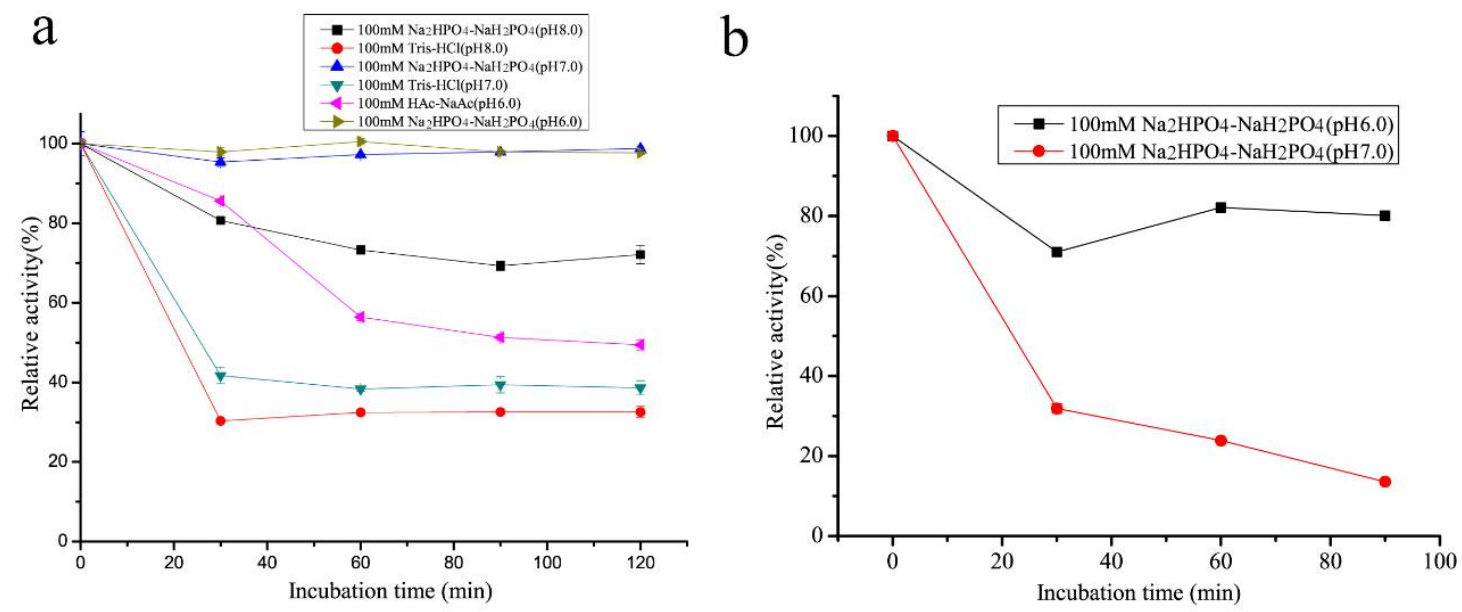

Figure 6. Effect comparison of different buffers on thermal stability of rSAGL from P. pastoris. Two temperatures of $50{ }^{\circ} \mathrm{C}(\mathbf{a})$ and $55{ }^{\circ} \mathrm{C}(\mathbf{b})$ were used in the test. In the residual activity test, $\mathrm{Na}_{2} \mathrm{HPO}_{4}-\mathrm{NaH}_{2} \mathrm{PO}_{4}$ buffer $\left(100 \mathrm{mM}, \mathrm{pH}\right.$ 6.0) and sodium alginate $(10 \mathrm{~g} / \mathrm{L})$ were used at $50{ }^{\circ} \mathrm{C}$. All experiments were conducted in triplicate, and the data were expressed as mean \pm standard deviation.

Table 3. Catalytic property comparisons of some endo-type alginate lyases.

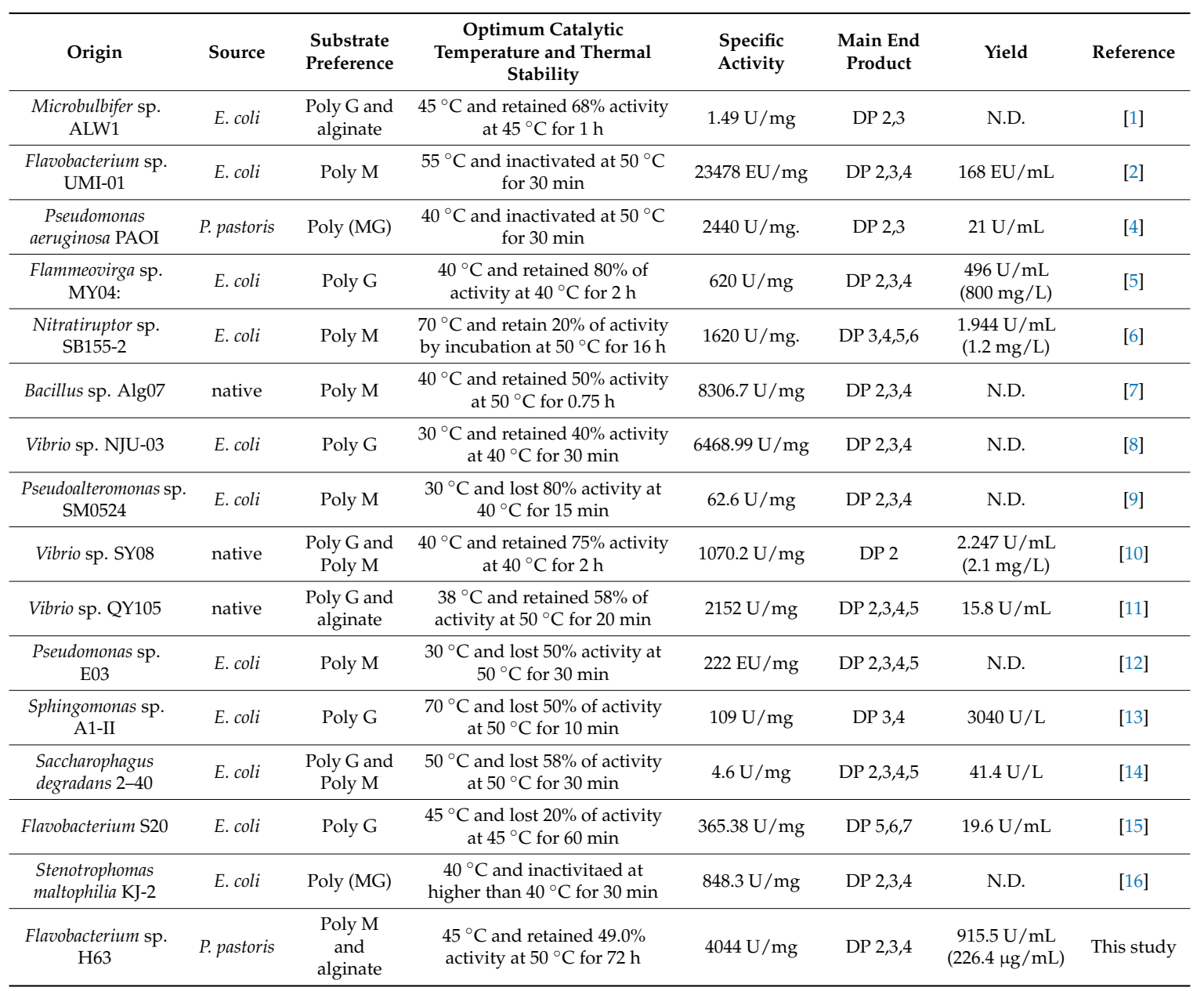




\subsection{Phylogenetic Tree Analysis of Sagl Based on Amino Acid Sequence}

In order to analyze the evolution relationship of sagl (MG792316) with known alginate lyases, a phylogenetic tree was constructed (Figure 7). Some alginate lyases in Table 3 were selected in construction. sagl (MG792316) has the nearest relationship with two alginate lyases AB898059 and JF412659, which were also from Flavobacterium genus. Alginate lyase of Pseudomonas aeruginosa PAOI (U27829), which was the first alginate lyase recombinantly expressed using P. pastoris system, had the farthest evolutionary relationship with sagl. The thermal stability difference between two recombinant alginate lyases perhaps were results of far evolutionary distance.

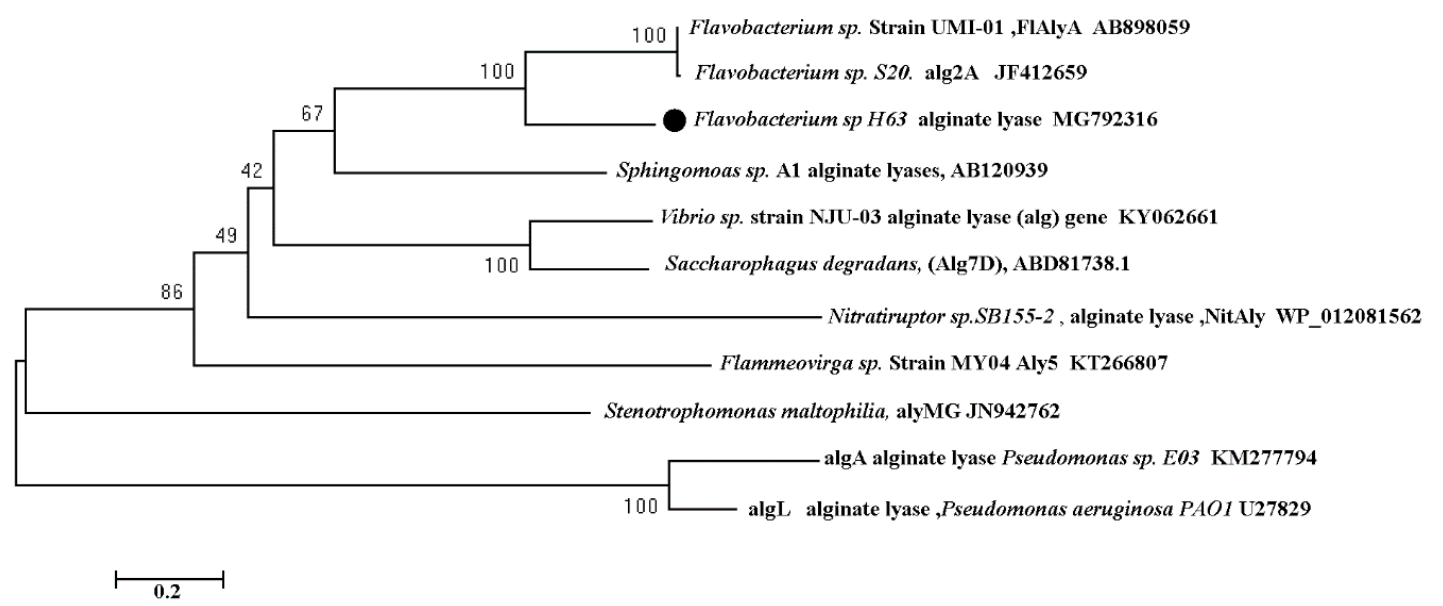

Figure 7. Phylogenetic tree analysis of sagl based on amino acid sequence. The neighbor-joining method was used in construction.

\subsection{High Density Fermentation}

In previous reports, the yields of some recombinant proteins produced by Pichia yeast reached gram level through various parameters optimization. In order to obtain higher yield of recombinant alginate lyase of sagl, fed-batch fermentation was carried out in $10 \mathrm{~L}$ fermentor according to standard high-density fermentation protocol. Firstly, the culture samples were collected at $12 \mathrm{~h}$ interval and the protein expression in fermentation was tested by SDS-PAGE and western-blotting. The results are shown in Figure $8 \mathrm{a}$. From $48 \mathrm{~h}$ of fermentation, recombinant SAGL including glycosylated and unglycosylated bands both could be detected. The amount of unglycosylated rSAGL was more and more until end of $168 \mathrm{~h}$ fermentation. However, after $144 \mathrm{~h}$, the glycosylated band was gradually not detected. Western blot results in Figure $8 \mathrm{~b}$ confirmed again that $35 \mathrm{KDa}$ and $32 \mathrm{KDa}$ bands both are rSAGL protein.

Next, enzyme activity and cell growth variation curves during rSAGL expression were determined. The results were shown in Figure 9. After the glycerol batch phase, glycerol fed-batch phase, and methanol fed-batch phase, the wet cell weight reached $424 \mathrm{~g} / \mathrm{L}$, the maximum alginate lyase activity in the supernatant of BSM medium reached $915.5 \mathrm{U} / \mathrm{mL}$ (Figure 9). By referring to the specific activity of $4044 \mathrm{U} / \mathrm{mg}$ protein, we concluded that the yield of recombinant alginate lyase enzyme reached $226.4 \mu \mathrm{g} / \mathrm{mL}$. This yield of $915.5 \mathrm{U} / \mathrm{mL}$ was 9.8 times higher than that of the shake flask fermentation, which was $95 \mathrm{U} / \mathrm{mL}$ (equal to $23.1 \mu \mathrm{g} / \mathrm{mL}$ ) (Figure 1a). The yield of rSAGL produced by P. pastoris was impressively higher than yields of other recombinant alginate lyases produced in E. coli system in previous reports (Table 3). The highest yield of them was $496 \mathrm{U} / \mathrm{mL}$ ( $800 \mathrm{mg} / \mathrm{L}$ ) [5]. In only one example of recombinant alginate lyase produced in P. pastoris system, the yield data was not shown [4]. Our study was the first report of high-level recombinant expression of alginate lyase in the P. pastoris system (Table 3). It was speculated that P. pastoris was a more suitable system than E. coli for high-level production of recombinant alginate lyase. 


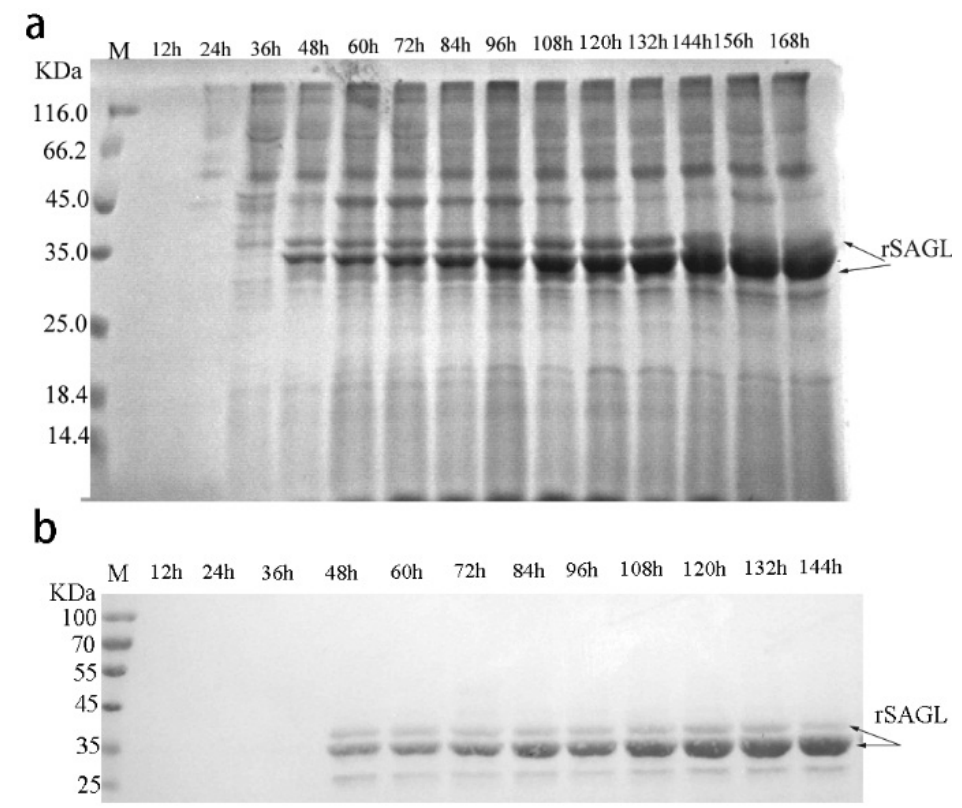

Figure 8. Expression analysis of recombinant SAGL in fermentor. (a) SDS-PAGE analysis of SAGL expression in fermentor. BSM medium was used in test. Culture supernatant samples collected at $12 \mathrm{~h}$ intervals were tested by electrophoresis. The target protein bands represented rSAGL were marked by arrows; (b) Western blot of culture supernatant of recombinant yeast. Lane M protein marker; culture samples from fermenters at $12,24,36,48,60,72,84,96,108,120,132$, and 144 here tested in turn at the following lanes.

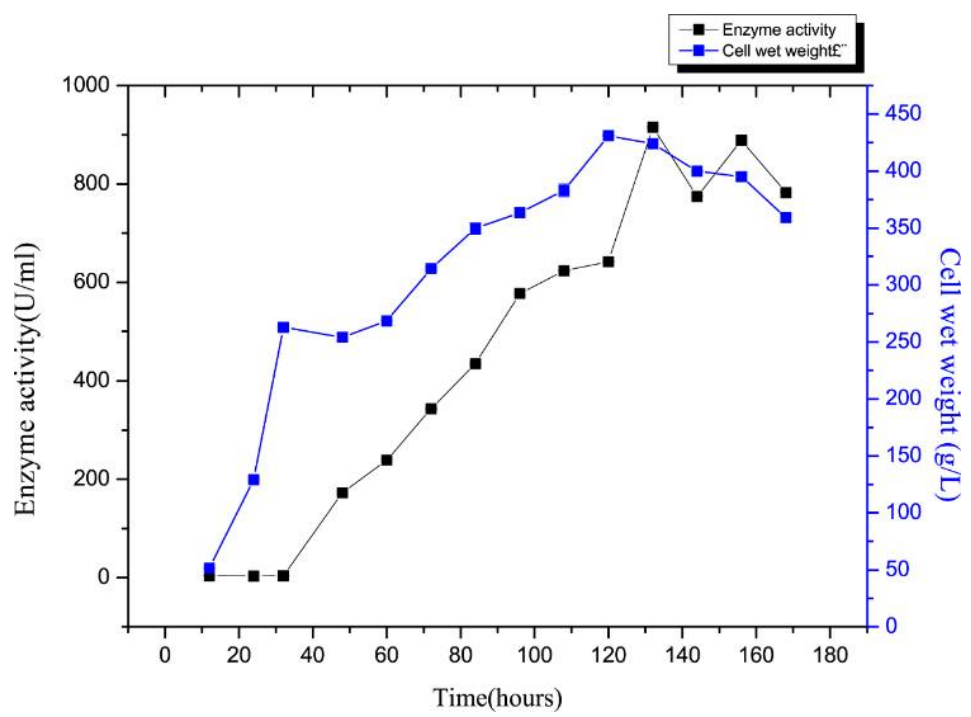

Figure 9. Enzyme activity and cell growth variation curves during rSAGL expression in fermentor. Samples were collected at 12, 24, 32, 48, 60, 72, 84, 96, 108, 120,132, 144, 156, and $168 \mathrm{~h}$. All experiments were conducted in triplicate, and the data were expressed as mean \pm standard deviation.

\subsection{Production and Analysis of Brown Alginate Oligosaccharide}

Sodium alginate was used as substrate to produce brown alginate oligosaccharide in large scale. For convenience, crude enzyme of rSAGL, which was supernatant of yeast fermentation culture, was directly used in production. In the transformation course, the amount of released reducing sugar that was calculated by using glucose equivalent in the reaction mixture was shown in Figure 10. 


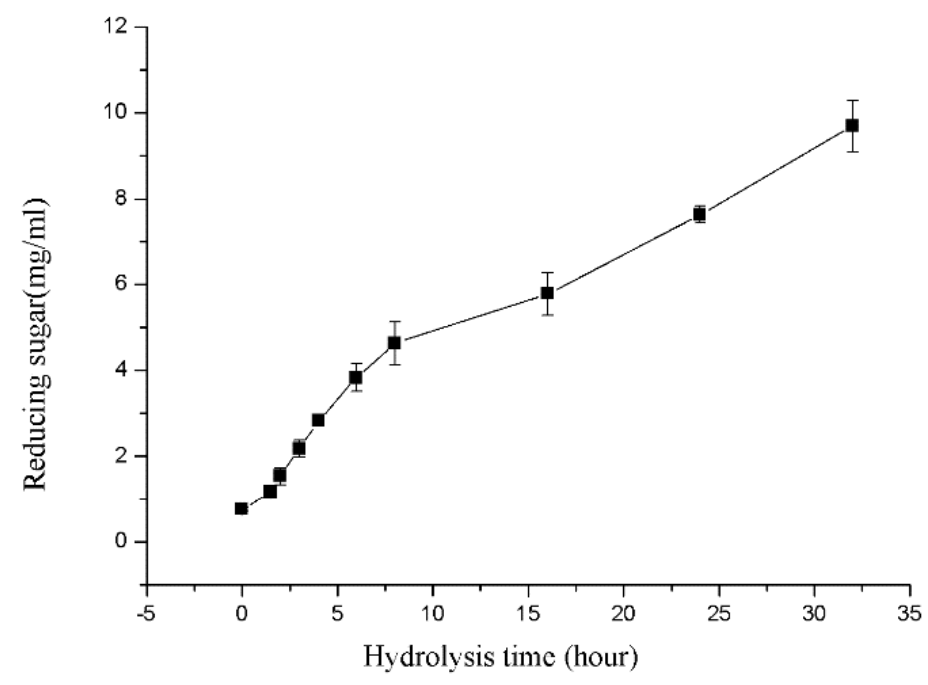

Figure 10. Reducing sugar concentration variation curves during large scale hydrolysis of sodium alginate substrate. Samples were collected at 1.5, 2, 3, 4, 6, 8, 16, 24, and $32 \mathrm{~h}$. All experiments were conducted in triplicate, and the data were expressed as mean \pm standard deviation.

The final concentration of reducing sugar in the mixture reached $9.51 \mathrm{~g} / \mathrm{L}$ at the end of $32 \mathrm{~h}$ hydrolysis course. After filtration, the oligosaccharide solution was freeze-dried to solid powder. Finally, $97.2 \%$ of transformation rate of sodium alginate was obtained. TLC (Thin layer chromatography) results showed that main oligosaccharide products were disaccharide, trisaccharide, and tetrasaccharide (Figure 11). These results suggested that rSAGL with high activity and thermal stability was a good candidate enzyme for industrial production of brown alginate oligosaccharide with low molecular weight.

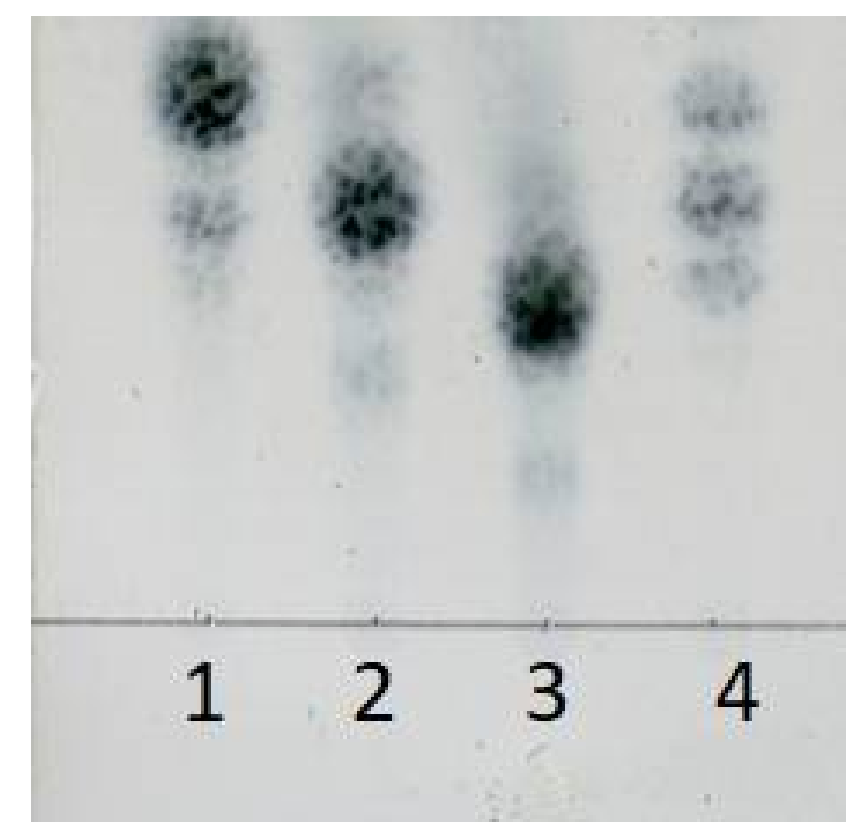

Figure 11. TLC analysis of oligosaccharide product of large-scale hydrolysis of sodium alginate substrate. Lane 1: L-diguluronic acid disodium salt and L-dimannuronic acid disodium salt; lane 2: L-triguluronic acid disodium salt and L-trimannuronic acid disodium salt; lane 3: L-tetraguluronic acid disodium salt and L-tetramannuronic acid disodium salt; lane 4: oligosaccharide product solution. Above standard compounds were used by equal molar mass in test. 


\section{Materials and Methods}

\subsection{Expression of Alginate Lyase in E. coli System}

For E. coli expression, pET28a vector and host cell BL21(DE3) were purchased from Novagen (Merck, Darmstadt, Germany). The 923 base pairs (bp) nucleotide acid sequence of an alginate lyase encoding gene from Flavobacterium sp. H63 was named as nagl and registered in Genbank with accession number MH234061. This nagl gene was ligated into pET28a vector at NdeI and HindIII sites. This recombinant vector named pET28a-nagl was confirmed by sequencing and transformed into BL21(DE3) competent cells. The induction, expression, and purification of recombinant alginate lyase of nagl was proceeded according to protocols of Molecular Cloning Handbook: A Laboratory Manual (Third Edition).

\subsection{Strain and Plasmid of Pichia System}

Both the yeast expression vector $\mathrm{pPICZ} \alpha \mathrm{A}$ and yeast host strain Pichia pastoris $\mathrm{X} 33$ were purchased from Invitrogen (Thermo Fisher, Waltham, MA, USA).

\subsection{Gene Cloning and Construction of Recombinant Yeast Expression Vector In Vitro}

The alginate lyase encoding gene from Flavobacterium sp. H63 was optimized according to Pichia pastoris codon usage bias. This gene sequence was named as sagl and registered in Genbank with accession number MG792316. The recombinant expression vector was constructed by inserting this sagl gene into pPICZ $\alpha$ A vector at EcoRI and NotI sites. This recombinant vector was confirmed by sequencing.

\subsection{Transformation and Colony Screening of P. pastoris}

The transformation and expression protocols of $P$. pastoris were mainly according to the P. pastoris expression manual of previously Invitrogen; Life Technologies (Carlsbad, CA, USA). Briefly, the recombinant $\mathrm{PPICZ} \alpha \mathrm{A}$ vector harbouring alginate lyase gene was linearized by using SacII and transformed into P. pastoris X33 competent cell. All positive recombinant yeast colonies were inoculated on BMGY plates. Two days later, all colonies were transferred onto BMMY plates supplemented with $10 \mathrm{~g} / \mathrm{L}$ sodium alginate (CAS 9005-38-3, sigma 180947) and $10 \mathrm{~g} / \mathrm{L}$ methanol. Five days later, each plate was sprayed with $1 \mathrm{~mL}$ of $10 \%(w / v)$ hexadecylpyridinium chloride (CAS 6004-24-6, sigma c9002) solution. The diameters of both yeast colonies and hydrolytic ring around the colonies were measured. The yeast colony with high ratio of the diameter of hydrolytic ring to that of yeast colony was selected for further shaking flask fermentation test.

\subsection{Shaking Flask Fermentation Test}

The yeast fermentation in $250 \mathrm{~mL}$ shaking flask was carried out according to the P. pastoris expression manual. A recombinant yeast colony was inoculated in $100 \mathrm{~mL}$ of BMGY medium containing $100 \mathrm{mM}$ potassium phosphate of $\mathrm{pH} 6.0,1.34 \%(w / v)$ yeast nitrogen base (YNB), $4 \times 10^{-5} \%$ $(w / v)$ biotin, and $10 \mathrm{~g} / \mathrm{L}$ glycerol. After culture at $28{ }^{\circ} \mathrm{C}$ for $48 \mathrm{~h}$, the cells were collected by centrifugation and re-suspended in $25 \mathrm{~mL}$ of BMMY medium supplemented with $100 \mathrm{mM}$ potassium phosphate of $\mathrm{pH} 6.0,1.34 \%(w / v)$ of $\mathrm{YNB}$ and $4 \times 10^{-5 \%}(w / v)$ biotin. The initial optical density value of culture at $600 \mathrm{~nm}$ was adjusted to 1.0. The incubation temperature was set at $28{ }^{\circ} \mathrm{C}$, the rotate speed was $250 \mathrm{rpm}$. The methanol with working concentration of $5 \mathrm{~g} / \mathrm{L}$ was feed at $0,24,48,72,96,120$, and $144 \mathrm{~h}$. During the induction course, supernatants samples were collected at $0,24,48,72,96,120$, 144, and $168 \mathrm{~h}$. Protein expression in samples was analyzed by using SDS-PAGE. 


\subsection{Recombinant Enzyme Purification, Western Blotting and Activity Assay}

The recombinant SAGL enzyme was purified from shaking flask medium supernatant using Ni-NTA resin. The substrate for activity assay was $10 \mathrm{mg} / \mathrm{mL}$ of sodium alginate solution prepared using $100 \mathrm{mM} \mathrm{Na}_{2} \mathrm{HPO}_{4}-\mathrm{NaH}_{2} \mathrm{PO}_{4}$ buffer of $\mathrm{pH}$ 6.0. The reaction mixture composed of $1 \mathrm{~mL}$ of substrate and $5 \mu \mathrm{L}$ of enzyme was incubated at $50{ }^{\circ} \mathrm{C}$ for $10 \mathrm{~min}$ without stirring. The reducing sugar content was determined by using DNS reagent. Glucose was used in standard curve construction. One enzyme unit was defined as the amount of enzyme that could release one micro molar glucose per minutes in above reaction. The protein concentration of the enzyme was assayed using the Bradford method. The deglycosylation treatment was done with EndoH (NEB). A total of $20 \mu \mathrm{L}$ of purified rSAGL enzyme was incubated with $2.0 \mathrm{IU}$ of EndoH at $37^{\circ} \mathrm{C}$ for $3 \mathrm{~h}$ according to the instructions of manufacturer. Then, the reaction mixture was analyzed using SDS-PAGE. The purified rSAGL was also tested using western blotting. The first antibody was mouse anti His antibody, and the second antibody was HRP-labeled Goat Anti-Mouse IgG (H + L). DAB Horseradish Peroxidase Color Development Kit was used to stain target protein band.

\subsection{Substrate Specificity Determination}

PolyM (poly- $\beta$-D-mannuronate), polyG (poly- $\alpha$-L-guluronate), and sodium alginate were dissolved respectively in $100 \mathrm{mM} \mathrm{Na} 2 \mathrm{HPO}_{4}-\mathrm{NaH}_{2} \mathrm{PO}_{4}$ buffer ( $\mathrm{pH}$ 7.0) with $4 \mathrm{mg} / \mathrm{mL}$ working concentration and used as substrate in this test. PolyM and polyG were purchased from BZ OLIGO Company (Qingdao, China). Reactions were initiated by adding appropriate enzyme, and the amount of yielded unsaturated uronic acid was monitored by recording the absorbance of the reaction mixture at $235 \mathrm{~nm}$.

\subsection{Characterization of Optimal Reaction Temperature and $p H$}

The optimal catalytic temperature was investigated in the range from $40{ }^{\circ} \mathrm{C}$ to $60^{\circ} \mathrm{C}$. The reaction buffer was $100 \mathrm{mM} \mathrm{Na} 2 \mathrm{HPO}_{4}-\mathrm{NaH}_{2} \mathrm{PO}_{4}$ buffer of $\mathrm{pH}$ 7.0. The optimal catalytic $\mathrm{pH}$ value was investigated in the range from 3.0 to 11.0. The reaction buffers were $50 \mathrm{mM} \mathrm{NaAc-HAc}$ buffer (pH 3.0, 4.0, 5.0, 6.0); $50 \mathrm{mM} \mathrm{Na} 2 \mathrm{HPO}_{4}-\mathrm{NaH}_{2} \mathrm{PO}_{4}$ buffer (pH 6.0, 7.0, 8.0); and $50 \mathrm{mM}$ glycine-NaOH buffer ( $\mathrm{pH} 8.0,9.0,10.0,11.0)$. The reaction mixture composed of $10 \mathrm{mg}$ sodium alginate and $5 \mu \mathrm{L}$ enzyme preparation in $1 \mathrm{~mL}$ buffer was incubated at $50{ }^{\circ} \mathrm{C}$ for $10 \mathrm{~min}$ without stirring. The reducing sugar content was determined using DNS reagent.

\subsection{Characterization of Thermal Stability}

The test of T50 value which was important parameters of enzyme thermal stability was proceeded as in previous reports [6]. The preparation of enzyme was incubated in $50 \mathrm{mM} \mathrm{Na}_{2} \mathrm{HPO}_{4}-\mathrm{NaH}_{2} \mathrm{PO}_{4}$ buffer ( $\mathrm{pH}$ 7.0) at $25-55^{\circ} \mathrm{C}$ for $30 \mathrm{~min}$. After incubation, these samples were transferred into an ice-bath for quick cooling. The residual enzyme activity of sample was determined using the standard method. The plot of T50 was made using temperature as horizontal coordinates and ratio of residual activity and initial activity as vertical coordinates. The test was conducted three times for every sample.

Next, the buffer effect on thermal stability was tested. Six types of buffer including $50 \mathrm{mM}$ $\mathrm{Na}_{2} \mathrm{HPO}_{4}-\mathrm{NaH}_{2} \mathrm{PO}_{4}$ buffer ( $\mathrm{pH}$ 6.0, 7.0, 8.0), $50 \mathrm{mM}$ Tris- $\mathrm{HCl}$ buffer ( $\mathrm{pH} 7.0,8.0$ ), and $50 \mathrm{mM}$ NaAc-HAc buffer ( $\mathrm{pH}$ 6.0) were used in tests. The incubation temperature for the buffer test was adjusted to $50{ }^{\circ} \mathrm{C}$. The residual activities of enzyme samples during incubation were determined at 30 min intervals.

\subsection{Characterization of Metal Ions Effects}

Metal ions effects were tested at $1 \mathrm{mM}$ and $10 \mathrm{mM}$ working concentration. $\mathrm{Na}^{+}$and $\mathrm{K}^{+}$with concentration range from $10 \mathrm{mM}$ to $500 \mathrm{mM}$ were tested separately. The reaction condition was same to the above activity assay condition. 


\subsection{ESI-MS and TLC Analysis of End Oligosaccharide Product}

The oligosaccharide product prepared through hydrolysis of sodium alginate substrate was analyzed by TLC and ESI-MS. In the hydrolysis reaction mixture, $0.1 \mathrm{~g}$ of sodium alginate and $9 \mathrm{~mL}$ of $100 \mathrm{mM} \mathrm{NaH}{ }_{2} \mathrm{PO}_{4}-\mathrm{Na}_{2} \mathrm{HPO}_{4}$ buffer ( $\mathrm{pH}$ 6.0) were mixed in the beaker by vigorous stirring for $30 \mathrm{~min}$. After adding 10 units of purified enzyme, the reaction mixture was incubated in a water-bath of $50{ }^{\circ} \mathrm{C}$. The stirring speed was adjusted to $200 \mathrm{rpm}$. After reaction course of $8 \mathrm{~h}$, protein and salts in the hydrolyzes were removed using Savage reagent and nanofiltration membrane (ESNA1 4040, Nitto Group Company, Oceanside, CA, USA), separately. The Savage reagent was a mixture of chloroform/1-butanol with volume ratio of 4:1. The oligosaccharide product was analyzed by using ESI-MS. The hydrolyzed products were concentrated, freeze-dried, and redissolved in $1 \mathrm{~mL}$ methanol. An amount of $2 \mu \mathrm{L}$ of supernatant was loop-injected to Waters 2795 HPLC system with dual wavelength UV detector, and ZQ single quadrupole MS with electrospray ionization source. The oligosaccharides products were detected in a positive-ion mode using the following settings: ion source voltage, $4.5 \mathrm{kV}$; capillary temperature, $275-300{ }^{\circ} \mathrm{C}$; Tube lens, $250 \mathrm{~V}$; sheath gas, 30 arbitrary units (AU); scanning the mass range, 150-2000 $\mathrm{m} / \mathrm{z}$. In the TLC analysis of oligosaccharide product, TLC plate (Silica Gel 60 F 254, Merck) was used. The solvent system was 1-butanol/formic acid/water (4:6:1, $v / v)$. After chromatography plates was sprayed with $10 \%(v / v)$ sulfuric acid in ethanol and heated at $130{ }^{\circ} \mathrm{C}$ for $5 \mathrm{~min}$ to visualize spots of oligosaccharide. Six standard oligosaccharide compounds of L-diguluronic acid salt, L-triguluronic acid salt, L-tetraguluronic acid salt, L-dimannuronic acid salt, L-trimannuronic acid salt, and L-tetramannuronic acid salt were purchased from BZ OLIGO Company (Qingdao, China). The above six compounds all are disodium salts. They were mixed and used as markers in chromatography.

\subsection{High Cell-Density Fermentation of Recombinant Alginate Lyase in P. pastoris}

In the course of high cell-density fermentation, basal salt medium (BSM) was used. The medium preparation protocol was referred to "Pichia Expression Manual" and "Pichia Fermentation Process Guidelines" of Invitrogen. Recombinant P. pastoris strain was inoculated into a flask containing $300 \mathrm{~mL}$ BMGY medium, and incubated at $30{ }^{\circ} \mathrm{C}, 250 \mathrm{rpm}$ for $48 \mathrm{~h}$, and then $300 \mathrm{~mL}$ BMGY medium were transferred to 6 L BMGY medium in a 10-L Biostat B plus fermenter (B. Braun Biotech International, $\mathrm{GmbH}$, Melsungen, Germany). The system was maintained at $30{ }^{\circ} \mathrm{C}, \mathrm{pH} 5.3$ (with $28 \% \mathrm{NH}_{4} \mathrm{OH}$ ) and $30 \%$ dissolved $\mathrm{O}_{2}$. After the glycerol was exhausted, $12 \mathrm{~mL}$ PTM1 trace salts/L (Invitrogen) with $50 \%(v / v)$ glycerol was fed continuously. The glycerol feeding rate was $18 \mathrm{~mL} / \mathrm{h} / \mathrm{L}$ for another $2-4 \mathrm{~h}$ until the OD $600 \mathrm{~nm}$ of the cell culture reached 180 . Next, 100\% methanol with $12 \mathrm{~mL}$ PTM1 trace salts/L was added to induce the expression of alginate lyase. The initial methanol concentration was adjusted to $30 \mathrm{~g} / \mathrm{L}$. The ratio of methanol content to wet weight of cells was about 0.2 . This ratio was maintained by methanol feed-batch. About $10 \mathrm{~mL}$ cell culture was collected every $24 \mathrm{~h}$ for SDS-PAGE, western blotting, and enzyme activity assays. In western blotting, the first antibody was mouse anti His antibody and the second antibody was HRP-labeled Goat Anti-Mouse IgG (H + L). DAB Horseradish Peroxidase Color Development Kit was used to stain target protein band. The fermentation course lasted $168 \mathrm{~h}$. The supernatant of culture separated by centrifugation was directly used as crude rSAGL enzyme.

\subsection{Enzymatic Production of Alginate Oligosaccharide}

Sodium alginate was used as substrate to produce oligosaccharide. Amounts of $100 \mathrm{~kg}$ substrate and $900 \mathrm{~L} \mathrm{NaH}_{2} \mathrm{PO}_{4}-\mathrm{Na}_{2} \mathrm{HPO}_{4}$ buffer $(100 \mathrm{mM}$, pH 6.0) were mixed in a stainless reactor by vigorous stirring for $30 \mathrm{~min}$. An amount of $300 \mathrm{~mL}$ of crude rSAGL enzyme with about $300 \mathrm{~K}$ enzyme units were added into the above mixture. The reaction temperature and the stirring speed were adjusted to $50{ }^{\circ} \mathrm{C}$ and $200 \mathrm{rpm}$. The reducing sugar contents of mixtures in reaction course were determined at intervals by using the DNS method. After $32 \mathrm{~h}$ of transformation, the temperature of mixture rose 
to $70{ }^{\circ} \mathrm{C}$ for $15 \mathrm{~min}$ to inactive enzyme and stop reaction. After centrifugation, the supernatant was harvested for further filtration using $0.22 \mu \mathrm{m}$ microporous filters. Next, the filtrate solution containing oligosaccharide was freeze-dried until the total solid reached constant weight. Oligosaccharide product weight was obtained by subtracting the weight of $\mathrm{NaH}_{2} \mathrm{PO}_{4}-\mathrm{Na}_{2} \mathrm{HPO}_{4}$ in the buffer from the solid weight. The transformation rate of substrate was the percentage of oligosaccharide weight to initial weight of sodium alginate. Freeze-dried oligosaccharide powder was redissolved by water and analyzed by using TLC.

\section{Conclusions}

In conclusion, a recombinant yeast strains high-level-expressed alginate lyase was successfully constructed in this study. This recombinant alginate lyase with high thermal stability and specific activity was high-level produced by high density fermentation. The yield of $226.4 \mu \mathrm{g} / \mathrm{mL}(915.5 \mathrm{U} / \mathrm{mL})$ was the highest record of alginate lyase production so far, and the recombinant enzyme was successfully applied in production of brown alginate oligosaccharide. It was speculated that the Pichia pastoris system was more suitable than the $E$. coli system for recombinant expression of marine polysaccharide transformation enzyme. Further investigation of this enzyme about molecular modification has been proceeded.

Author Contributions: H.L. was responsible for the experiment design and data determination. Y.Z. was responsible for the data processing and manuscript preparation. S.W. was responsible for experiment design and English correction. L.C. was responsible for oligosaccharide analysis.

Acknowledgments: This work was supported by the Public Welfare Technology and Application Project of Zhejiang Province (2015C37058) and the Medical Scientific Research Project of Zhejiang Province (2018KY034).

Conflicts of Interest: The authors declare no conflict of interest.

\section{References}

1. Zhu, Y.; Wu, L.; Chen, Y.; Ni, H.; Xiao, A.; Cai, H. Characterization of an extracellular biofunctional alginate lyase from marine Microbulbifer sp. ALW1 and antioxidant activity of enzymatic hydrolysates. Microbiol. Res. 2016, 182, 49-58. [CrossRef] [PubMed]

2. Inoue, A.; Takadono, K.; Nishiyama, R.; Tajima, K.; Kobayashi, T.; Ojima, T. Characterization of an Alginate Lyase, FlAlyA, from Flavobacterium sp. Strain UMI-01 and Its Expression in Escherichia coli. Mar. Drugs 2014, 12, 4693-4712. [CrossRef] [PubMed]

3. Kang, L.X.; Chen, X.M.; Fu, L.; Ma, L.X. Recombinant expression of chitosanase from Bacillus subtilis HD145 in Pichia pastoris. Carbohyd. Res. 2012, 352, 37-43. [CrossRef] [PubMed]

4. Yue, M.M.; Gong, W.W.; Qiao, Y.; Ding, H. A Method for Efficient Expression of Pseudomonas aeruginosa Alginate Lyase in Pichia pastoris. Prep. Biochem. Biotechnol. 2016, 46, 165-170. [CrossRef] [PubMed]

5. Han, W.; Gu, J.; Cheng, Y.; Liu, H.; Li, Y.; Li, F. Novel Alginate Lyase (Aly5) from a PolysaccharideDegrading Marine Bacterium, Flammeovirga sp. Strain MY04: Effects of Module Truncation on Biochemical. Characteristics, Alginate Degradation Patterns, and Oligosaccharide-Yielding Properties. Appl. Environ. Microb. 2015, 82, 364. [CrossRef] [PubMed]

6. Inoue, A.; Anraku, M.; Nakagawa, S.; Ojima, T. Discovery of a Novel Alginate Lyase from Nitratiruptor sp. SB155-2 Thriving at Deep-sea Hydrothermal Vents and Identification of the Residues Responsible for Its Heat Stability. J. Biol. Chem. 2016, 291, 15551-15563. [CrossRef] [PubMed]

7. Chen, P.; Zhu, Y.M.; Men, Y.; Zeng, Y.; Sun, Y.X. Purification and Characterization of a Novel Alginate Lyase from the Marine Bacterium Bacillus sp. Alg07. Mar. Drugs 2018, 16, 86. [CrossRef] [PubMed]

8. Zhu, B.W.; Sun, Y.; Ni, F.; Ning, L.M.; Yao, Z. Characterization of a new endo-type alginate lyase from Vibrio sp. NJU-03. Int. J. Biol. Macromol. 2018, 108, 1140-1147. [CrossRef] [PubMed]

9. Chen, X.L.; Sheng, D.; Fei, X.; Fang, D.; Li, P.Y.; Zhang, X.Y.; Zhou, B.C.; Zhang, Y.Z.; Xie, B.B. Characterization of a New Cold-Adapted and Salt-Activated Polysaccharide Lyase Family 7 Alginate Lyase from Pseudoalteromonas sp. SM0524. Front. Microbiol. 2016, 7, 1120. [CrossRef] [PubMed]

10. Li, S.; Wang, L.; Hao, J.; Xing, M.; Sun, J.; Sun, M. Purification and Characterization of a New Alginate Lyase from Marine Bacterium Vibrio sp. SY08. Mar. Drugs 2017, 15, 1-11. [CrossRef] [PubMed] 
11. Wang, Y.; Guo, E.W.; Yu, W.G.; Han, F. Purification and characterization of a new alginate lyase from a marine bacterium Vibrio sp. Biotechnol. Lett. 2013, 35, 703-708. [CrossRef] [PubMed]

12. Zhu, B.W.; Huang, L.S.; Tan, H.D.; Qin, Y.Q.; Du, Y.G.; Yin, H. Characterization of a new endo-type polyM-specific alginate lyase from Pseudomonas sp. Biotechnol. Lett. 2015, 37, 409-415. [CrossRef] [PubMed]

13. Hye-Jin, Y.; Hashimoto, W.; Osamu Miyake, M.O.; Mikami, B.; Murata, K. Overexpression in Escherichia coli, purification, and characterization of Sphingomonas sp. A1 alginate lyases. Protein Expr. Purif. 2000, 19, 84-90. [CrossRef]

14. Kim, H.T.; Ko, H.J.; Kim, N.; Kim, D.; Lee, D.; Choi, I.G.; Woo, H.C.; Kim, M.D.; Kim, K.H. Characterization of a recombinant endo-type alginate lyase (Alg7D) from Saccharophagus degradans. Biotechnol. Lett. 2012, 34, 1087-1092. [CrossRef] [PubMed]

15. Huang, L.; Zhou, J.; Li, X.; Peng, Q.; Lu, H.; Du, Y. Characterization of a new alginate lyase from newly isolated Flavobacterium sp. S20. J. Ind. Microbiol. Biotechnol. 2013, 40, 113-122. [CrossRef] [PubMed]

16. Lee, S.I.; Choi, S.H.; Lee, E.Y.; Kim, H.S. Molecular cloning, purification, and characterization of a novel polyMG-specific alginate lyase responsible for alginate MG block degradation in Stenotrophomas maltophilia KJ-2. Appl. Microbiol. Biotechnol. 2012, 95, 1643-1653. [CrossRef] [PubMed]

(C) 2018 by the authors. Licensee MDPI, Basel, Switzerland. This article is an open access article distributed under the terms and conditions of the Creative Commons Attribution (CC BY) license (http:/ / creativecommons.org/licenses/by/4.0/). 